Zeszyty Naukowe Szkoły Głównej Gospodarstwa Wiejskiego w Warszawie Problemy Rolnictwa Światowego tom 17 (XXXII), zeszyt 2, 2017: 41-47

DOI: 10.22630/PRS.2017.17.2.25

Sylwia Goląb $^{1}$, Małgorzata Szcześniak ${ }^{2}$

${ }^{1}$ Zachodniopomorski Uniwersytet Technologiczny w Szczecinie

${ }^{2}$ Uniwersytet Szczeciński

\title{
Satysfakcja z pracy a poczucie jakości życia na przykładzie osób z terenów wiejskich - doniesienia wstępne
}

\section{Satisfaction with Work and Quality of Life on the Example of People from Rural Areas - Preliminary Reports}

\begin{abstract}
Synopsis. Celem opracowania jest dyskusja nad problemem jakości życia osób z terenów wiejskich. Przedstawione analizy stanowią wycinek badań empirycznych i dotyczą jednego z wielu aspektów poruszanego tematu - satysfakcji z pracy. Badanie przeprowadzono wśród 68 osób aktywnych zawodowo zamieszkujących tereny wiejskie w województwie zachodniopomorskim. W badaniach wykorzystano Kwestionariusz Poczucia Jakości Życia autorstwa Straś-Romanowskiej, Anny Oleszkowicz, Tomasza Frąckowiaka i Skalę Satysfakcji z Pracy opracowaną przez Zalewską. Wykonano analizę regresji wielokrotnej za pomocą metody krokowej. Wyniki badań wskazują, że wyższy poziom jakości życia w sferze psychospołecznej i sferze podmiotowej zwiększaja prawdopodobieństwo wyższego poziomu satysfakcji z pracy. Zadowolenie z pracy koreluje istotnie statystycznie i pozytywnie z ogólnym poczuciem jakości życia i pozostałymi jego wymiarami.
\end{abstract}

Słowa kluczowe: satysfakcja z pracy, jakość życia, dobrostan, obszary wiejskie

\begin{abstract}
The purpose of the study is to discuss the quality of life of people from rural areas. The presented analyzes are a part of empirical research and cover one of many aspects of the subject - job satisfaction. The study was conducted among 68 professionally active people living in rural areas in the voivodeship of Zachodniopomorskie. In the research the following questionnaires were used: Questionnaire of Life Quality by Straś-Romanowska, Anna Oleszkowicz, Tomasz Frąckowiak and Job Satisfaction Scale developed by Zalewska. Multiple regression analysis was performed, using the step method. Research shows that higher quality of life in the psychosocial and subjective sphere increases the likelihood of higher levels of job satisfaction. Satisfaction with work correlates statistically and positively with a general sense of quality of life and other dimensions.
\end{abstract}

Keywords: job satisfaction, quality of life, well-being, rural areas

\section{Wprowadzenie}

Jakość życia najczęściej utożsamiana jest z dobrobytem i dobrostanem, jednakże wielowątkowość i złożoność tego zagadnienia spowodowały, iż zakres rozumienia tej kategorii jest bardzo szeroki. Jakość życia jest pojęciem, na które składa się wiele elementów, takich jak potrzeby i warunki materialne, potrzeby duchowe, potrzeba bezpieczeństwa związana $\mathrm{z}$ zabezpieczeniem finansowym oraz pracą $\mathrm{i}$ wiele innych. Termin ,jakość życia” nie jest łatwo zdefiniować, także dlatego, że łączy w sobie wiele

\footnotetext{
${ }^{1}$ dr, Wydział Ekonomiczny ZUT w Szczecinie, ul. Żołnierska 47, 71-210 Szczecin,

e-mail: sylwia.golab@zut.edu.pl

${ }^{2}$ dr, Instytut Psychologii, Uniwersytet Szczeciński, e-mail: malgorzata.szczesniak@whus.pl
} 
różnych aspektów: psychologicznych, ekonomicznych, statystycznych, socjologicznych, antropologicznych, czy medycznych (Ostasiewicz, 2004). Dlatego też szczególnie wartościowe mogą okazać się badania interdyscyplinarne, łączące różne podejścia i aspekty omawianego zagadnienia. Prezentowane opracowanie jest próbą określenia, czy aktywność zawodowa i związana z nią satysfakcja z pracy zawodowej jest determinantą lepszej jakości życia (w wymiarze subiektywnym) osób $\mathrm{z}$ terenów wiejskich. Jako punkt odniesienia niniejszego opracowania przyjęto podejście psychologiczno-ekonomiczne. Zaprezentowane wyniki badań stanowią wycinek rzeczywistości w warunkach polskiej wsi. Należy także podkreślić, że poniższe rozważania mają postać wstępnych ustaleń, dotyczących wybranych aspektów tworzących subiektywną ocenę jakości życia mieszkańców gmin wiejskich.

\section{Przegląd literatury}

Na podstawie przeglądu literatury można wyciagnnąc wniosek, że istnieje wiele niejednoznaczności w definiowaniu tego pojęcia. Pomimo dużego zainteresowania problematyką poziomu życia, brakuje jednej, uniwersalnej definicji oraz badawczych operacjonalizacji. Rozbieżności w rozumieniu omawianego zagadnienia dotyczą nie tylko badaczy różnych dyscyplin naukowych, ale także przedstawicieli reprezentujących te same dziedziny wiedzy. Taka sytuacja wynika głównie z interdyscyplinarnej natury tego pojęcia, a także $\mathrm{z}$ koncentrowania się na różnych aspektach jakości życia (Sompolska-Rzechuła, 2013) oraz z faktu, że jakość życia jako zjawisko wielowymiarowe, często ma charakter ideologiczny, ewaluatywny, może być też uwikłane w konteksty polityczne i kulturowe (Adamiec, Popiołek, 1993). B. Poskrobko (2007) wskazuje, że jakość życia, powiązana ze szczęściem i zadowoleniem, powinna być ujmowana w kontekście relacji między wartościami, stylami; potrzebami i warunkami życia.

W naukach społecznych wskazuje się, iż przy opisie jakości życia istotne jest zarówno uwzględnienie determinantów obiektywnych, jak i subiektywnych (Sompolska-Rzechuła, 2013). Badania w zakresie obiektywnej jakości życia odzwierciedlają dobrobyt ekonomiczny, analizy zatem dotyczą warunków życia jednostek i zbiorowości w odniesieniu do sytuacji materialnej, zabezpieczenia egzystencjalnego i środowiska (Słaby, 2007). Kryk (2013) wskazuje, że oprócz społecznej, ekonomicznej i środowiskowej jakości życia, można wyróżnić czwartą dziedzinę - instytucjonalno-administracyjną. Z kolei wymiar subiektywny dotyczy odczuć psychicznych jednostek, determinowanych przyjętym systemem wartości i funkcjonowaniem $\mathrm{w}$ określonych warunkach społecznych, gospodarczych i politycznych (Borys, Rogala, 2008). Warto podkreślić, że uzasadnione jest rozróżnienie obiektywnych i subiektywnych aspektów jakości życia, nie tylko ze względów poznawczych, ale także przydatności w badaniach (Borys, 2008). Jakość życia można także traktować jako kategorię wyrażającą samorealizację człowieka w ujęciu holistycznym, uwzględniającą zarówno fizyczny, psychiczny, jak i społeczny (w tym zawodowy) wymiar (Borys 2001). Ze względu na wieloaspektowe ujęcie jakości życia wynikające między innymi z powiązań, jakie występują między procesami ekonomicznymi i społecznymi, pomiar tej kategorii jest zadaniem trudnym. Pomimo badań interdyscyplinarnych z zakresu ekonomii, socjologii i psychologii nie udało się opracować spójnej metodologii badań, która umożliwiłyby odpowiedź na pytanie dotyczące wpływu poszczególnych czynników na zaspokojenie potrzeb jednostek, czyli na jakość ich życia (Słaby 2007). W niniejszym 
badaniu wykorzystano model poczucia jakości życia autorstwa Marii Straś-Romanowskiej (2005). Według koncepcji Autorki, na poziom poczucia jakości życia składają się nie tylko zjawiska biologiczne i społeczne, ale także podmiotowe i duchowe. Jest to ujęcia holistyczne, które obejmuje różne aspekty funkcjonowania człowieka i odnosi się do subiektywnej oceny jakości życia przez jednostkę.

Istotnym czynnikiem, który należy uwzględnić w badaniach oceniających jakość życia jest praca zawodowa. Jednym $\mathrm{z}$ uwarunkowań funkcjonowania człowieka $\mathrm{w}$ pracy jest odczuwanie przez niego zadowolenia i satysfakcji z pracy, które przekładają się nie tylko na jego efektywność, ale także na szeroko rozumianą jakość życia. Praca jako ważny element jakości życia, znacząco wpływa na zaspokojenie potrzeb. To w miejscu pracy człowiek spędza znaczną część doby, więc także całego życia, warto także podkreślić, że wynagrodzenie za pracę umożliwia zaspokajanie różnorodnych potrzeb, związanych z codziennym funkcjonowaniem, samorealizacja, a także zabezpiecza życie i zdrowie. Jakość pracy zawodowej powinna iść w parze z jakością życia (Skrzypek 2001). Pomimo, że na ogół wyższy poziom satysfakcji z pracy warunkuje wyższy poziom satysfakcji z życia (Wudarzewski, 2013), należy zauważyć, że w wielu opracowaniach wskazuje się, że im bardziej jednostka wiąże swą satysfakcję życiową z realizacją celów materialnych, tym mniejszą odczuwa satysfakcję $\mathrm{w}$ takich obszarach, jak standard życia, życie rodzinne, relacje interpersonalne, zabawa, rozrywka (Mudyń, Pietras, 2007). Korzystając z ustaleń Paruzel-Czachury (2013) w niniejszych badaniach przyjęto, że satysfakcja z pracy pociaga za sobą wzrost ogólnego poczucia jakości życia:

H1: Satysfakcja z pracy koreluje pozytywnie z poczuciem jakości życia. Im wyższy poziom zadowolenia z pracy, tym wyższy poziom ogólnego poczucia jakości życia i sfery psychofizycznej, psychospołecznej, podmiotowej oraz duchowej (metafizycznej).

H2: Wymiary ogólnego poczucia jakości życia (psychofizyczny, psychospołeczny, podmiotowy i duchowy) pozwalają przewidzieć satysfakcję z pracy.

Należy podkreślić, że przedstawiony w niniejszym opracowaniu sposób rozumienia satysfakcji z pracy odwołuje się do wskaźników subiektywnych, czyli ocen samej osoby, klasyfikując ją jako ocenę poznawczą, sąd wartościujący, a nie stan emocjonalny (por. Laguna 2012).

\section{Materiał i metody}

Badanie przeprowadzono wśród 68 osób aktywnych zawodowo ( $65 \%$ kobiet) w wieku od 20 do 58 roku życia $(M=27,16 ; \mathrm{SD}=8,05)$. Średnia ogólnego stażu pracy wyniosła 21,73 miesięcy $(\mathrm{SD}=44,21)$, z czego $60 \%$ respondentów przepracowała więcej niż 2 miesiące. Uczestnicy badania pochodzili $\mathrm{z}$ terenów wiejskich $\mathrm{w}$ województwie zachodniopomorskim.

W celu weryfikacji hipotez zastosowano: Kwestionariusz Poczucia Jakości Życia autorstwa Straś-Romanowskiej, Anny Oleszkowicz, Tomasza Frąckowiaka i Skalę Satysfakcji z Pracy opracowaną przez Zalewską (2003; 2006). Kwestionariusze zostały wypełnione formą ,papier-ołówek”.

Kwestionariusz Poczucia Jakości Życia składa się z czterech wymiarów dotyczących sfer: psychofizycznej, psychospołecznej, podmiotowej i metafizycznej. Teoretyczną podstawą do jego powstania była koncepcja człowieka wielowymiarowego (StraśRomanowska, Frąckowiak, 2007), złożonego, o niejednorodnej strukturze potrzeb i dążeń 
(Frąckowiak, 2012). Obszar psychofizyczny jakości wiąże się z cielesnością człowieka, popędowością, zdrowiem fizycznym i psychicznym. Sfera psychospołeczna obejmuje pytania o tożsamość, przynależność społeczną jednostki i jej miejsce w grupie. Wymiar podmiotowy wyraża indywidualność i niezależność podmiotu, dążącego do samorealizacji i osiagania stawianych sobie celów. Sfera metafizyczna dotyczy duchowości, autotranscendencji i wiąże się z poczuciem sensu życia (Straś-Romanowska, 2005). Badany określa, w jakim stopniu zgadza się z każdym z 60 twierdzeń, zaznaczając na skali wartość od 1 (zdecydowanie nie zgadzam się) do 4 (zdecydowanie zgadzam się). Twierdzenia o charakterze negatywnym wymagają inwersji, czyli odwrócenia punktacji. Miarą stopnia poczucia jakości życia jest suma punktów. Im niższy wynik, tym jej ocena jest wyższa. Rzetelność dla całej skali, mierzona współczynnikiem $\alpha$ Cronbacha, w przeprowadzonym badaniu wyniosła 0,847 (sfera psychofizyczna $\alpha=0,51$; psychospołeczna $\alpha=0,79$; podmiotowa $\alpha=0,78$; metafizyczna $\alpha=0,58$ ).

Skala Satysfakcji z Pracy jest inspirowana kwestionariuszem The Satisfaction With Life Scale(SWLS) Dienera i in. (1985). Technika jest oparta na pięciu sądach wartościujących, dotyczących satysfakcji z pracy, rozumianej jako całościowe, złożone zjawisko. Respondenci odpowiadają na 7-punktowej skali (1-zdecydowanie się nie zgadzam, 7-zdecydowanie się zgadzam), umieszczając wartość, najbardziej odpowiadająca ich opinii. Analiza czynnikowa metodą głównych składowych (rotacja varimax) wyłoniła, podobnie jak w skali oryginalnej, jeden czynnik o wartości własnej większej od 1, wyjaśniający prawie $61 \%$ wariancji. Współczynnik a Cronbacha w niniejszym badaniu wyniósł 0,827 .

Analizy statystyczne nieodzowne do weryfikacji zaproponowanych hipotez wykonano w programie IBM SPSS Statistics w wersji 20. Przy jego użyciu wyliczono podstawowe statystyki opisowe analizowanych zmiennych ilościowych, przetestowano normalność ich rozkładów, wykonano analizę korelacji $r$ Pearsona, analizę regresji wielokrotnej za pomocą metody krokowej, oraz analizę supresji tradycyjnej. Przyjęto klasyczny próg istotności $p<0,05$ a wyniki pomiędzy wartościami $0,05<p<0,1$ uznawano za istotne na poziomie tendencji statystycznej.

\section{Wyniki badań}

W pierwszej kolejności przeanalizowano średni poziom poczucia jakości życia wśród badanych. Wyniósł on $198,79(\mathrm{SD}=18,98)$ przy wyniku minimalnym 153 i najwyższym 235. Uzyskaną średnią można uznać za wynik wysoki w porównaniu do przeciętnego uzyskanego w podobnych badaniach (Paruzel-Czachura, 2013).

Następnie sprawdzono hipotezę 1, dotyczącą zależności pomiędzy satysfakcją z pracy a ogólnym poczuciem jakości życia oraz jego wymiarami: psychofizycznym, psychospołecznym, podmiotowym i metafizycznym (tab. 1). Korelacja $r$ Pearsona wykazała, że zadowolenie z pracy koreluje istotnie statystycznie i pozytywnie z ogólnym poczuciem jakości życia i pozostałymi jego wymiarami. Nie zaobserwowano korelacji znaczących pomiędzy satysfakcją z pracy, a stażem wykonywanego zawodu i wiekiem.

Celem pogłębienia omówionych analiz, zweryfikowano również, które zmienne poczucia jakości życia pozwalają istotnie statystycznie przewidywać poziom satysfakcji z pracy (hipoteza 2). Dokonano tego za pomocą analizy regresji wielokrotnej przy użyciu metody krokowej. Jako zmienne wyjaśniające uwzględniono poszczególne wymiary 
poczucia jakości życia. Uzyskane wyniki wskazują (tab. 2), że predyktorem wyjaśniającym samodzielnie największy odsetek (26\%) wariancji satysfakcji $\mathrm{z}$ pracy jest sfera psychospołeczna. Nie bez znaczenia było jednak dodanie do modelu sfery podmiotowej, dzięki czemu procent wyjaśnionej wariancji zmiennej wzrósł istotnie statystycznie. Ten model wyjaśnia łącznie $33 \%$ zmienności satysfakcji z pracy. Wartości współczynnika standaryzowanego $\beta$ świadczą, że wyższy poziom jakości życia w sferze psychospołecznej i sferze podmiotowej zwiększają prawdopodobieństwo wyższego poziomu satysfakcji z pracy.

Tabela 1. Korelacje między satysfakcją z pracy a ogólnym poczuciem jakości życia i wymiarami (N=68)

Table 1. Correlation coefficients between the job satisfaction and general sense of quality of life $(\mathrm{N}=68)$

\begin{tabular}{|c|c|c|c|c|c|c|c|c|}
\hline & 1 & 2 & 3 & 4 & 5 & 6 & 7 & 8 \\
\hline Satysfakcja z pracy (1) & 1 & & & & & & & \\
\hline Ogólne poczucie jakości życia (2) & $.508 * *$ & 1 & & & & & & \\
\hline Sfera psychofizyczna & $.257 *$ & $.836^{* *}$ & 1 & & & & & \\
\hline Sfera psychospołeczna & $.510 * *$ & $.816^{* *}$ & $.566^{* *}$ & 1 & & & & \\
\hline Sfera podmiotowa & $.484 * *$ & $.787 * *$ & $.556^{* *}$ & $.488 * *$ & 1 & & & \\
\hline Sfera metafizyczna & $.386 * *$ & $.627 * *$ & $.282 *$ & $.484 * *$ & $.390 * *$ & 1 & & \\
\hline Staż pracy & -.065 & -.199 & -.099 & -.181 & -.144 & $-.238^{\mathrm{t}}$ & 1 & \\
\hline Wiek & .035 & .202 & $.252 *$ & .094 & .173 & .056 & $.284 * *$ & 1 \\
\hline
\end{tabular}

Źródło: obliczenia własne.

Tabela 2. Współczynniki analizy regresji dla zmiennej zależnej w postaci równowagi postaw życiowych dla wszystkich badanych

Table 2. The coefficients of regression analysis for the dependent variable in the form of life balance equations for all respondents

\begin{tabular}{l|cccccc}
\hline & $B$ & $S E$ & $\mathrm{~B}$ & $R^{2}$ & $\Delta R^{2}$ & $F_{\text {zmiany }}$ \\
\hline model 1 & & & & 0,26 & 0,25 & $23,19 * * *$ \\
(Stała) & $-10,18$ & 6,21 & & & \\
Sfera psychospołeczna & 0,577 & 0,12 & $0,51 * * *$ & & & $16,20^{* * *}$ \\
model 2 & & & & & \\
(Stała) & $-18,64$ & 6,74 & & & \\
Sfera psychospołeczna & 0,407 & 0,13 & $0,36 * *$ & & & \\
Sfera podmiotowa & 0,355 & 0,13 & $0,31 *$ & & & \\
\hline$*$ - $p<0,05 * * *-p<0,01 ; * * *$ &
\end{tabular}

Źródło: obliczenia własne.

Wyniki zaprezentowanych badań znajdują swoje potwierdzenie w badaniach empirycznych, których celem było wyodrębnienie czynników związanych z zadowoleniem z pracy. Na przykład, Roberts i Chapman (2000) oraz Scollon i Diener (2006) odkryli, że wzrostowi satysfakcji $\mathrm{z}$ pracy towarzyszył wzrost ekstrawersji, czyli czynnika wyrażającego się w ilości i jakości interakcji społecznych. Nie bez znaczenia wydają się 
być również w tym kontekście badania nad satysfakcją z pracy a poczuciem przynależności do zespołu (sense of belonging). Odczucie, że jest się członkiem grupy pracowniczej, dzielenie z nią celów, świadomość bycia ważnym ogniwem systemu i przekonanie o akceptacji ze strony innych, stanowią podstawową potrzebę ludzką, która jeśli zostanie zaspokojona, prowadzi do uczucia satysfakcji z pracy. To prowadzi do zaangażowania $\mathrm{w}$ pracę (work engagement) i wyraża się w zadowoleniu z jej wykonywania (Byrne, 2015; Shimazu, Schaufeli, Kamiyama, Kawakami, 2015). Zatem, wymiar psychospołeczny jest jak najbardziej uzasadniony jako predyktor satysfakcji z pracy.

Z kolei, inne analizy wykazały, że satysfakcja z pracy była pozytywnie skorelowana $\mathrm{z}$ postrzeganym wsparciem przełożonego w aspekcie autonomii (Gillet, Fouquereau, Forest, Brunault, Colombat (2012). Jeśli weźmiemy pod uwage, że autonomia i niezależność w pracy wiążą się $\mathrm{z}$ możliwością podejmowania samodzielnych decyzji i swobodą $\mathrm{w}$ realizacji zadań (Jurek, 2014), to zrozumiały jest pozytywny związek pomiędzy indywidualnością i niezależnością jednostki a jej zadowoleniem $\mathrm{z}$ pracy, które charakteryzują wymiar podmiotowy jakości życia. Ponadto, w innych badaniach zaobserwowano (Orpen, 1985) iż satysfakcja z pracy była znacząco wyższa wśród menedżerów, którzy charakteryzowali się wysokim pragnieniem osiagnięć i potrzebą niezależności aniżeli wśród kadry kierowniczej, mającej niższe wyniki w tych aspektach.

\section{Podsumowanie}

Celem badań była próba określenia, czy aktywność zawodowa i związana z nią satysfakcja z pracy zawodowej jest determinantą lepszej jakości życia (w wymiarze subiektywnym) osób z terenów wiejskich. Zgodnie z przyjętymi hipotezami, wszystkie wymiary ogólnego poczucia jakości życia korelowały pozytywnie z satysfakcją z życia i niektóre z nich zostały jej predyktorami: wymiar psychospołeczny i wymiar podmiotowy.

Pomimo, że zaprezentowane analizy stanowią wycinek prowadzonych badań empirycznych, wskazują one na istnienie zależności pomiędzy satysfakcją z pracy, a ogólnym poczuciem jakości życia oraz jego wymiarami: psychofizycznym, psychospołecznym, podmiotowym i metafizycznym.

Ze względu na wieloaspektowość omawianego zagadnienia konieczne jest prowadzenie merytorycznie pogłębionych badań z tego zakresu, uwzględniających zarówno podejścia ilościowe, jak i jakościowe. Analizy, które zostały przeprowadzone jedynie w oparciu o aspekty subiektywne postrzegania życia $\mathrm{w}$ kontekście wykonywanej pracy zawodowej, warto byłoby rozszerzyć o czynniki ekonomiczne, które odnoszą się do obiektywnych wartości. Zasadnym byłoby także dokonanie porównania jakości życia mieszkańców wsi i miast z uwzględnieniem aspektów materialnych (obszar, infrastruktura, edukacja, itp.) i niematerialnych (możliwości) miasta.

\section{Literatura}

Adamiec, M. Popiołek, K. (1993). Jakość życia - między wolnością a mistyfikacją. Ruch Prawniczy, Ekonomiczny i Socjologiczny, 2, 92-117.

Borys, T. (2001). Jakość życia jako kategoria badawcza i cel nadrzędny, W: A. Wachowiak (red.) Jak żyć? (s. 17-39), Wydawnictwo Fundacji Humaniora, Poznań.

Borys, T., Rogala, P. (2008). Jakość życia na poziomie lokalnym - ujęcie wskaźnikowe, UNDP, Warszawa. 
Borys, T. (2008). Propozycja siedmiu typologii jakości życia. Prace Naukowe Akademii Ekonomicznej we Wrockawiu. Gospodarka a Środowisko, 9(22), 125-126.

Byrne, Z. S. (2015). Understanding employee engagement: Theory, research, and practice. New York: Routledge.

Diener, E., Emmons, R.A., Larsen, R. J., Griffin, S. (1985). The Satisfaction With Life Scale. Journal of Personality Assessment, 49, 71-75.

Frąckowiak, T. (2012). Poczucie jakości życia osób długowiecznych. Psychologia Rozwojowa, 17(1), 101-115.

Gillet, N., Fouquereau, E., Forest, J., Brunault, P., Colombat, P. (2012). The impact of organizational factors on psychological needs and their relations with well-being. Journal of Business Psychology, 27, 437-450.

Jurek, P. (2014). Hierarchia wartości zawodowych osób poszukujących pracy. W: A.M. Zawadzka, M. Niesiobędzka, D. Godlewska-Werner (red.). Kultura konsumpcji - wartości, cele, dobrostan. Psychologiczne aspekty zjawiska (s. 139-158). Warszawa: LiberiLibri.

Kędzior, Z. (2003). Metodologiczne aspekty badania jakości życia, W: Jakość życia w regionie (s.15-16), J. Karwowski (red.). US, PAN, Szczecin.

Kryk, B. (2013). Jakość życia - odczuwać czy mierzyć W: Poziom i jakość życia w dobie kryzysu, Z. Wyszkowska, M. Gotowska (red.) Wydawnictwo Uczelniane Uniwersytetu Technologiczno-Przyrodniczego w Bydgoszczy, Bydgoszcz.

Łaguna, M. (2012). Satysfakcja z życia i satysfakcja z pracy a motywacja do podejmowania szkoleń: Doniesienie z badań. Psychologia Jakości Życia, 11(2), 163-172.

Mudyń, K., Pietras, K. (2007). Preferowane wartości a zdrowie i satysfakcja z życia. Psychoterapia 1(140), 5-25.

Orpen, C. (1985). The effects of need for achievement and need for independence on the relationship between perceived job attributes and managerial satisfaction and performance. International Journal of Psychology, $20,207-219$

Ostasiewicz, W. (2004). Badanie jakości życia z perspektywy historycznej, W: W. Ostasiewicz (red.) Ocena i analiza jakości życia, Wydawnictwo Akademii Ekonomicznej im. Oskara Langego we Wrocławiu, Wrocław.

Paruzel-Czachura, M. (2013). Poczucie jakości życia i poziom wyczerpania witalnego u aktywnych zawodowo kobiet i mężczyzn. Studia Psychologica 13(1), 5-24.

Poskrobko, B. (2007). Ku ekonomii zrównoważonego rozwoju, w: Obszary badań nad trwałym i zrównoważonym rozwojem, Ekonomia i Środowisko, Białystok, 13.

Roberts, B.W., Chapman, C. (2000). Change in dispositional well-being and its relation to role quality. Journal of Research in Personality, 34(1), 26-41.

Scollon, C.N., Diener, E. (2006). Love, work, and changes in extraversion and neuroticism over time. Journal of Personality and Social Psychology, 91(6), 1152-1165.

Shimazu, A., Schaufeli, W.B., Kamiyama, K., Kawakami, N. (2015). Workaholism vs. work engagement: The two different predictors of future well-being and performance. International Journal of Behavioral Medicine, $22(1), 18-23$.

Słaby, T. (2007). Nowe propozycje w badaniach jakości życia. Studia i Prace Kolegium Zarzqdzania i Finansów $S G H, 108,125-127$

Sompolska-Rzechuła, A. (2013). Jakość życia jako kategoria ekonomiczna, Folia Pomeranae Universitatis Technologiae Stetinensis, Oeconomica 301(71), 127-140.

Skrzypek, E. (2001). Czynniki kształtujące jakość życia, w: Ergonomia niepełnosprawnym - jakość życia, red. J. Lewandowski, J. Lecewicz-Bartoszewska, wyd. Politechniki Łódzkiej, Łódź, 239.

Straś-Romanowska, M. (2005). Jakość życia w świetle założeń psychologii zorientowanej na osobę. Kolokwia Psychologiczne, 13, Wydawnictwo Instytut Psychologii PAN. Warszawa, 263-274.

Straś-Romanowska M., Frąckowiak, T. (2007), Rola relacji międzyludzkich w budowaniu jakości życia osób niepełnosprawnych (perspektywa personalistyczno-egzystencjalna) W: J. Patkiewicz (red.), Rola więzi w rozwoju dzieci i młodzieży niepełnosprawnej, (s. 47-57). Wrocław: Wyd. TWK.

Wudarzewski, G. (2013) Satysfakcja z pracy - konceptualizacja pojęcia w świetle badań literaturowych, Zeszyty Naukowe WSB, Wrocław 5(37), 327.

Zalewska, A. (2003). „Skala Satysfakcji z Pracy” - pomiar poznawczego aspektu ogólnego zadowolenia z pracy. Acta Universitatis Lodziensis, Folia Psychologica, 7, 49-61.

Zalewska, A. (2006). Związki pomiędzy potrzebą aprobaty społecznej a zadowoleniem z pracy w badaniach anonimowych. Roczniki Psychologiczne, 9 (2), 29-44. 